\section{Mixed blessings for middle-aged mothers}

Perls et al. ${ }^{1}$ in Scientific Correspondence present intriguing data suggesting that bearing children in middle age may be a harbinger for extreme longevity. We have reanalysed another study, which does not lead to the same conclusion.

Perls et al. report a significant fourfold excess of births in middle age $(N=19$ women age 40 or older) among 78 female centenarians when compared with a group of 54 women in the same birth cohort (born in Massachusetts in 1896) who survived only to the age of 73. We re-examined this question using data derived from a large case-control of postmenopausal breast cancer in Massachusetts, New Hampshire and Wisconsin ${ }^{2}$. In that study, women provided detailed information on family history, including maternal and sibling dates of birth, survival status and dates of death, and data on socioeconomic status, race, religion and maternal smoking.

We identified the 3,578 mothers of control women (subjects without breast cancer) who survived at least to the age of $70(70 \%$ were deceased at the time of the daughter's interview). All were born between 1867 and 1923 (median, 1900), and 552 (15.4\%) had given birth after their fourth decade. In an unadjusted model, the mortality rate from all causes was slightly increased (by $11 \%$ ) in association with late childbirth (rate ratio, $1.11 ; 95 \%$ confidence interval, 1.01-1.23; $P=0.04)$. However, after adjusting for smoking and socioeconomic status, this excess disappeared (rate ratio, 1.01; 95\% confidence interval, $0.90-1.13 ; P=0.83$ ). Only 27 women lived to age 100 or beyond. Among the 1,167 women born in 1896 (the birth year of women in ref. 1) or earlier, the proportion bearing children after age 40 was higher in the 352 women who died between the ages of 70 and $79(31 \%)$ than in the 322 women who survived to age 90 (24\%). Thus, in this population of elderly parous women, all of whom had given birth to at least one child, we find no evidence that childbearing in 'middle age' is a reliable marker of longevity.

Kathleen M. Egan, Edward Giovannucci Linda Titus-Ernstoff, Polly Newcomb Meir Stampfer

Department of Epidemiology,

Harvard School of Public Health,

677 Huntington Avenue,

Boston, Massachusetts 02115, USA

e-mail: kathleen.egan@channing.harvard.edu

1. Perls, T. T., Alpert, L. \& Fretts, R. C. Nature 389, 133 (1997).

2. Newcomb, P. A. et al. Am. J. Epidemiol. 142, 788-795 (1995).

There are several explanations for the evolution of human longevity and senescence ${ }^{1,2}$, a recent example being the suggestion by
Perls et al. ${ }^{3}$ of a relationship between longevity in women and the age at which they bore children. Perls et al. showed that women surviving to at least age 100 were four times more likely to have had children while in their 40s than women who survived to age 73. But it is not possible to argue from these data that "the driving selective force of human lifespan is maximizing the period of time during which women can bear children" without a comparison of the total number of offspring produced (lifetime reproduction, LR) of the two groups of women.

Natural selection favours genes that increase $\mathrm{LR}^{2,4}$, and consequently analyses must be based on LR if they are to conclude that the length of the reproductive period in women is a driving force in the evolution of human lifespan. The interpretation of Perls et al. would be supported if women in the centenarian group had a larger LR than those who died at 73. Alternatively, if women in the second group had equal or larger LR than those in the other, the shorter lifespan is probably an expression of costs associated with child care at an earlier age.

Philipp Heeb, Martin W. G. Brinkhof

Zoology Department, University of Bern,

CH-3032 Hinterkappelen, Switzerland

e-mail:philipp.heeb@esh.unibe.ch

1. Neese, R. M. \& Williams, G. C. Evolution and Healing (Weinfelden \& Nicholson, London, 1995).

2. Stearns, S. C. The Evolution of Life Histories (Oxford Univ. Press, 1992).

3. Perls, T. T., Alpert, L. \& Fretts, R. C. Nature 389, 133 (1997).

4. Daan, S. \& Tinbergen, J. M. in Behavioural Ecology 4th edn (eds

Krebs, J. R. \& Davies, N. B.) 311-333 (Blackwell, Oxford, 1997).

In relation to the question of whether 'middle-aged' mothers live longer, raised recently in Scientific Correspondence ${ }^{1}$, there are of course many factors that influence longevity. Menopause is not only a reflection of ovarian ageing: it could primarily be a result of hypothalamic disturbances, including neurotoxic effects of endogenous oestrogens ${ }^{2}$. Further, later menopause is usually considered to be a risk factor for breast and endometrial cancer ${ }^{3,4}$.

Another factor affecting lifespan is smoking, which may strongly influence the timing of the onset of menopause, age at the time of last birth and longevity ${ }^{5}$. The connection between giving birth after age 40 and lifespan may be modulated by the number of times a woman has previously given birth $^{6}$. And the lifespan of female progeny of women giving birth for the last time after the age of 40 may be shorter than that of the progeny of younger mothers ${ }^{7}$. Additional investigation is needed before a definite conclusion can be drawn about the relationship between longevity and the age of parturition. Lev M. Berstein

Laboratory of Endocrinology,

N. N. Petrov Research Institute of Oncology,

St Petersburg 189646, Russia

e-mail:levmb@endocrin.spb.ru
1. Perls, T. T., Alpert, L. \& Fretts, R. C. Nature 389, 133 (1997).

2. Brawer, J. R. et al. Biol. Reprod. 49, 647-652 (1993).

3. MacMahon, B. et al. J. Natl Cancer Inst. 50, 21-42 (1973).

4. Brinton, L. A. et al. Am. J. Obst. Gynecol. 167, 1317-1325 (1992).

5. Berstein, L. M. Oncoendocrinology of Smoking (Nauka, St Petersburg, 1995).

6. Hytten, F. E. \& Leitch, I. The Physiology of Human Pregnancy (Blackwell Scientific, Oxford, 1971).

7. Gavrilov, L. A. et al. Proc. Acad. Sci. (Russia) 354, 569-572 (1997).

\section{Tree-ring dating the 1700 Cascadia earthquake}

Geological evidence shows that an earthquake attended by a tsunami, or a series of such earthquakes, ruptured at least $900 \mathrm{~km}$ of the Cascadia subduction zone along the west coast of North America between the years 1700 and $1720^{1}$. Satake et al. ${ }^{2}$ found evidence for one large tsunami of previously unknown origin in Japanese archives of that era, and used its time and size to propose that a Cascadia earthquake of magnitude 9 occurred on 26 January 1700. Tree-ring records from a central part of the Cascadia subduction zone now provide support for this proposal.

Much of the Cascadia coast between southern British Columbia and northern California was lowered abruptly as a result of an earthquake (or earthquakes) about 300 years ago ${ }^{1,3}$. In Washington state, coastal forests were submerged by more than a metre of tidewater ${ }^{4}$, damaging some trees and killing thousands of others. Several dozen Sitka spruce (Picea sitchensis) that survived this tidal submergence remain around the estuaries of southern Washington. Annual growth rings in half of the trees show changes in width and anatomy consistent with disturbance (tilting, increased flooding, or both) in the first few years after $1699^{5}$.

We instead used annual rings to date western red cedar (Thuja plicata) killed by

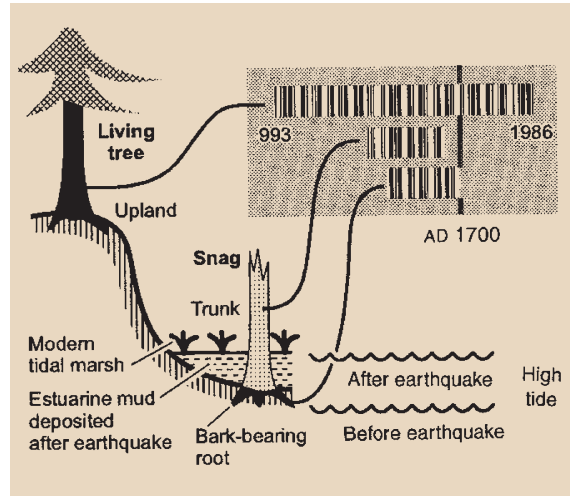

Figure 1 Approach for tree-ring dating of earthquake-induced submergence. Upland trees contain ring-width patterns that correlate with those of dead trees (snags) killed by tidal submergence. Final rings in snags have been lost on weather-beaten trunks but are preserved in bark-covered roots. Bar codes exaggerate ring-width correlations. 
Table 1 Dating of red cedar snags that retain intact roots

\begin{tabular}{|c|c|c|c|c|c|c|c|}
\hline \multirow[t]{2}{*}{ Estuary } & \multirow[t]{2}{*}{ Snag } & \multicolumn{3}{|c|}{ Trunk (or root, PX-J6 only) } & \multicolumn{3}{|c|}{ Root } \\
\hline & & $\begin{array}{l}\text { Sample } \\
\text { length } \\
\text { (yr) }\end{array}$ & $\begin{array}{c}\text { Outer } \\
\text { preserved } \\
\text { ring (year } A D \text { ) }\end{array}$ & $\begin{array}{c}\text { Correlation } \\
\text { with Long Island } \\
r, \log P\end{array}$ & $\begin{array}{l}\text { Sample } \\
\text { length } \\
\text { (yr) }\end{array}$ & $\begin{array}{l}\text { Outer ring } \\
\text { against bark } \\
\text { (year } \mathrm{AD} \text { ) }\end{array}$ & $\begin{array}{c}\text { Correlation } \\
\text { with trunk } \\
r, \log P\end{array}$ \\
\hline \multirow[t]{2}{*}{ Copalis River } & СР-791 & 283 & 1680 & $0.28,-3.42$ & ND & 1708 & $\mathrm{~T}$ \\
\hline & CP-GF2 & 255 & 1675 & $0.21,-0.76^{*}$ & 331 & $1699 \mathrm{~L}$ & $0.57,-21.39$ \\
\hline \multirow[t]{2}{*}{ Grays Harbor } & JN-560 & 295 & 1674 & $0.26,-2.71$ & ND & $1699 \mathrm{~L}$ & $\mathrm{~T}$ \\
\hline & JN-561 & 263 & 1678 & $0.44,-10.56$ & 248 & $1699 \mathrm{~L}$ & $0.35,-5.97$ \\
\hline \multirow[t]{3}{*}{ Willapa Bay } & PX-782 & 239 & 1681 & $0.52,-15.16$ & 355 & $1699 \mathrm{~L}$ & $0.42,-9.63 ; T$ \\
\hline & PX-783 & 340 & 1675 & $0.30,-5.59$ & 218 & $1699 \mathrm{~L}$ & $0.63,-20.71 ; T$ \\
\hline & PX-J6 & 202 & 1699 & $0.23,-0.54^{*}$ & ND & 1699 & ND \\
\hline Columbia River & GR-777 & 378 & 1671 & $0.27,-4.55$ & 90 & $1699 \mathrm{~L}$ & $\mathrm{~T}$ \\
\hline
\end{tabular}

$r$, correlation coefficient; $P$, probability of error in correlation; T, rings independently correlated by tracing from trunk to root. L, 1699 ring contains latewood. ND, not determined. Assumptions: trunks, 200-yr minimum overlap and a latest-possible date of 1720 based on radiocarbon'; roots, outer rings postdate those of trunks but are no later than 1720. Data from trees CP-GF2 and PX-J6 were from G. Jacoby. Samples were collected with L. Amidon, P. Atwater, K. Bevis, J. Boughner, S. Brown, M. Cisternas, S. Cooley, L. Davis, S. Fritts, N. Jacobson, J. Morales, P. Raskind, R. Lewis, J. C. Moya, K. Sayce, J. Shulene, F. Taylor, Y. Wang, K. Wegmann and A. Zachery.

*Correlations with securely dated snags at the same estuary (assuming a 150-yr minimum overlap): CP-GF2, $r=0.28$, $\log P=-3.18 ; \mathrm{PX}-\mathrm{J} 6, r=0.29, \log P=-2.16$.

the submergence (Fig. 1 and supplementary information). We first identifed consistent ring-width patterns in 19 upland trees on Long Island, Willapa Bay (studied with C. Woodhouse). These red cedar are rooted about $50 \mathrm{~m}$ above sea level, too high to have suffered from the submergence. Their composite ring-width pattern extends from $\mathrm{AD}$ 993 to 1986. Next we looked for segments of the Long Island pattern in the decayed trunks of 75 earthquake-killed trees (snags) in tidal wetlands of the Copalis River, Grays Harbor, Willapa Bay, and the Columbia River, along $90 \mathrm{~km}$ of the subduction zone. We identified such segments in 15 of the snags. The probability of error in these matches is less than 0.001 for 13 of the snags and less than 0.01 for the other two (examples in Table 1). We dated six additional snags by correlating them with these firmly dated trees.

Trunk rings from the last years before death have been lost because of exposure, but the dated trunk rings show that many of the red cedars died after the 1670s and 1680s. At least one snag from each of the four estuaries retains a trunk ring from 1680 or later, and a Columbia River snag extends to 1691 .

To date tree death more exactly we used bark-bearing roots of the snags, in collaboration with G. Jacoby. Of 12 snag roots sampled, eight gave reliable estimates of the final year of tree growth (Table 1). Concentric rings in roots of these eight snags can be counted as far as the bark along radii that had been the most rapidly growing before death. In seven of the eight snags, including one or more at each of the four estuaries, the final ring of the sampled root formed in 1699. The other snag gave an outer-ring date of 1708 , but the exceptional height of its dated root may have delayed death from tidal submergence.

Six of the snags narrow the time of tree death to the months between the end of the 1699 growing season (August) and the start of the 1700 growing season (May). In these snags, the final ring, which dates to 1699 , contains dark, late-summer cells where the ring is more than a few cells wide (L, Table 1). In the seventh snag, which has a final ring from 1699, the ring is too thin to show whether such latewood is present or not.

By converging so narrowly on January 1700 , these tree-ring dates securely link an earthquake inferred from geology at Cascadia with a tsunami known from documents in Japan. They thereby give the 1700 Cascadia earthquake a place in written history even though it predates the region's earliest documents ${ }^{6}$ by almost a century.

The dates provide a simple test of earthquake size. Suppose that the dates excluded January 1700 . In that case, the tsunami in Japan could not represent a 650-km-long rupture at Cascadia - the distance between the region of the dated snags and the far (California) end of the subduction zone. Because a $650-\mathrm{km}$-long rupture of the Cascadia would be too small for magnitude 9 (ref. 7), dates excluding January 1700 would thereby strengthen geophysical arguments ${ }^{8}$ against magnitude 9 earthquakes at Cascadia. By converging on January 1700, the dates mean that Canada and the northwestern United States are plausibly subject to earthquakes of magnitude 9.

\section{David K. Yamaguchi}

Department of Environmental Health,

University of Washington, Box 354695 ,

Seattle, Washington 98195, USA

e-mail:yamaguch@u.washington.edu

\section{Brian F. Atwater}

US Geological Survey,

Department of Geological Sciences,

University of Washington, Box 351310 ,

Seattle, Washington 98195, USA

Daniel E. Bunker

Tree-Ring Laboratory,

Lamont-Doherty Earth Observatory,

Palisades, New York 10964, USA

Boyd E. Benson

GeoEngineers Inc., 8410 154th Avenue N.E., Redmond, Washington 98052, USA

Marion S. Reid

The Nature Conservancy, 2060 Broadway,

Suite 230, Boulder, Colorado 80302, USA
1. Nelson, A. R. et al. Nature 378, 371-374 (1995).

2. Satake, K., Shimazaki, K., Tsuji, Y. \& Ueda, K. Nature 379, 246-249 (1996).

3. Atwater, B. F. et al. Earthquake Spectra 11, 1-18 (1995). 4. Hemphill-Haley, E. Geol. Soc. Am. Bull. 107, 367-378 (1995).

5. Jacoby, G. C., Bunker, D. E. \& Benson, B. E. Geology 25, 999-1002 (1997).

6. Heaton, T. H. \& Hartzell, S. H. Science 236, 162-168 (1987).

7. Hyndman, R. D. \& Wang, K. J. Geophys. Res. 100, 22133 (1995). 8. McCaffrey, R. \& Goldfinger, C. Science 267, 856-859 (1995).

Supplementary information is available on Nature's World-Wide Web site (http://www.nature.com) or as paper copy from Mary Sheehan at the London editorial office of Nature.

\section{Thermal contraction}

The Scientific Correspondence by Roy and Agrawal $^{1}$ commenting on a News and Views article by Robert $\mathrm{Cahn}^{2}$ states that their work had not been acknowledged by Cahn or by us. Cahn's article emphasized negative thermal expansion, but the three reviews mentioned by Roy and Agrawal are about low thermal expansion. All of our papers (refs 3-5 in ref. 2) prominently mention the work of Roy and Agrawal on the family of compounds based on $\mathrm{NaZr}_{2} \mathrm{P}_{3} \mathrm{O}_{12}$ (NZP). Further, the thermal expansion properties in the zirconium tungstate family ${ }^{3-5}$ highlighted by $\mathrm{Cahn}^{2}$ differ dramatically from other materials, including those of the NZP family. Roy and Agrawal stated that the unusual thermal expansion in the NZP family was discovered by them, but this was first seen by Boilot et al. ${ }^{6}$, as they acknowledge in their earlier papers ${ }^{7}$.

Possibly the most misleading part of Roy and Agrawal's contribution concerns a particular member of the NZP family, $\mathrm{NaTi}_{2} \mathrm{P}_{3} \mathrm{O}_{12}$. They give its thermal expansion as $-5.5 \times 10^{-6}$ per ${ }^{\circ} \mathrm{C}$, from measurements of the expansion of a ceramic body. In fact, the intrinsic linear thermal expansion of this material, on the basis of unit-cell changes with temperature, is $+4.3 \times 10^{-6}$ per ${ }^{\circ} \mathrm{C}$ (ref. 8).

Thermal expansion in the NZP family is usually highly anisotropic, as indeed it is for $\mathrm{NaZr}_{2} \mathrm{P}_{3} \mathrm{O}_{12}$ itself, the thermal expansion of individual crystals being strongly positive in one dimension and negative in two dimensions. The effects of anisotropic thermal expansion of crystallites on a ceramic body composed of such crystallites have long been known ${ }^{9}$. The inherent microcracking generally decreases mechanical strength, causes hysteresis in thermal expansion properties, changes the thermal expansion properties with thermal cycling, and causes a decrease in thermal expansion observed in ceramic bodies because the cracks tend to become larger with decreasing temperature. Ceramic bodies of $\mathrm{NaTi}_{2} \mathrm{P}_{3} \mathrm{O}_{12}$ normally show a thermal expansion less negative than the $-5.5 \times 10^{-6}$ per ${ }^{\circ} \mathrm{C}$ value quoted by Roy and Agrawal. However, in using a material to lower the thermal expansion of a composite, it is the intrinsic thermal expansion 